\title{
Correction to: Vibration induced injuries in hands in long-term vibration exposed workers
}

Lars Gerhardsson * and Mats Hagberg

\section{Correction to: J Occup Med Toxicol https://doi.org/10.1186/s12995-019-0242-0}

Following publication of the original article [1], it has been brought to our attention that an error was slipped into the article's title.

- Initially published title:

Style: J of occupational medicine and toxicology vibration induced injuries in hands in long-term vibration exposed workers

- Corrected title:

Vibration induced injuries in hands in long-term vibration exposed workers

The original article has been corrected.

Published online: 23 August 2019

\section{Reference}

1. Gerhardsson L, Hagberg M. Vibration induced injuries in hands in long-term vibration exposed workers. J Occup Med Toxicol. 2019;14:21. https://doi. org/10.1186/s12995-019-0242-0.

\footnotetext{
* Correspondence: lars.gerhardsson@amm.gu.se 